Original Article

\title{
Systematic analysis of leisler's bat Nyctalus leisleri (Kuhl, 1817) captured from FATA region, Pakistan
}

\author{
Análise sistemática do morcego de leisler Nyctalus leisleri (Kuhl, 1817) \\ capturado na região das FATA, Paquistão
}

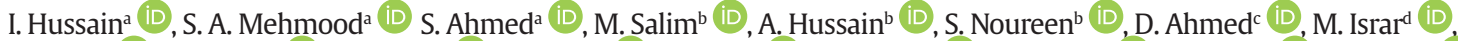

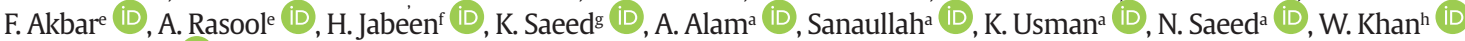 \\ and M. Shahi* iD \\ aDepartment of Zoology, Hazara University Mansehra, Khyber Pakhtunkhwa, Pakistan \\ ${ }^{b}$ Department of Forestry and Wildlife Management, University of Haripur, Khyber Pakhtunkhwa, Pakistan \\ 'Department of Forensic Sciences, University of Swat, Khyber Pakhtunkhwa, Pakistan \\ ${ }^{d}$ Centre for Biotechnology \& Microbiology, University of Swat, Khyber Pakhtunkhwa, Pakistan \\ eDepartment of Microbiology, Women University Mardan, Khyber Pakhtunkhwa, Pakistan \\ fDepartment of Zoology, University of Buner, Khyber Pakhtunkhwa, Pakistan \\ gDepartment of Zoology, University of Malakand, Chakdara, Khyber Pakhtunkhwa, Pakistan \\ ${ }^{\text {h}}$ Centre for Animal Science \& Fisheries, University of Swat, Khyber Pakhtunkhwa, Pakistan \\ iUniversity of Swat, Centre for Animal Science \& Fisheries, Saidu Sharif, Khyber Pakhtunkhwa, Pakistan
}

\begin{abstract}
Extensive field surveys were carried out to explore the distribution of Leisler's Bat Nyctalus leisleri (Kuhl, 1819) in selected area of FATA regions, Pakistan. Specimens of Leisler's Bat Nyctalus leisleri (Kuhl, 1819) (n5) were collected from Kurram Agency (Shublan) (N33.8229788 E70.1634414) at elevation 1427m and Khyber Agency (Landi Kotel) (N34.0909899 E71.1457517) at elevation 1091 m for two years survey extending from May 2013 through August 2015. The mean head and body length, hind foot length, ear length and tail length the Nyctalus leisleri specimens captured from the study area was $65.08 \pm 1.58 \mathrm{~mm}, 44.06 \pm 0.52 \mathrm{~mm}, 8.38 \pm 0.60 \mathrm{~mm}, 13.20 \pm 0.99 \mathrm{~mm}$ and $39.46 \pm 1.46 \mathrm{~mm}$, respectively. For molecular analysis the sequences of $\mathrm{COI}$ gene were obtained and analyzed. The mean intraspecific divergences of Nyctalus leisleri was $0.04 \%$. The mean interspecific divergences of Nyctalus noctula and Nyctalus leisleri was $0.2 \%$. The mean concentration of each nucleotides was $A=(26.3 \%), T=(32.8 \%), G=(15.9 \%)$ and $C=(25.0 \%)$. The mean $A+T$ contents were $59.2 \%$ and $C+G$ were $40.9 \%$. In the phylogenetic tree Nyctalus leisleri and Nyctalus noctula clustered with significant bootstrap support value.
\end{abstract}

Keywords: Nyctalus leisleri, morphology, Kurram Agency, Khyber agency, Pakistan.

\section{Resumo}

Extensas pesquisas de campo foram realizadas para explorar a distribuição do morcego de Leisler Nyctalus leisleri (Kuhl, 1819), em uma área selecionada das regiões das FATA, Paquistão. Espécimes do morcego de Leisler Nyctalus leisleri (Kuhl, 1819) ( $\mathrm{n}=5$ ) foram coletados na Agência Kurram (Shublan) (N33.8229788 E70.1634414), na elevação 1.427 m, e na Agência Khyber (Landi Kotel) (N34.0909899 E71.1457517), na elevação 1.091 m, por dois anos de pesquisa, estendendo-se de maio de 2013 a agosto de 2015. Os comprimentos médios da cabeça, do corpo, do pé traseiro, da orelha e da cauda dos espécimes de Nyctalus leisleri capturados na área de estudo foram de 65,08 $\pm 1,58 \mathrm{~mm}$, $44,06 \pm 0,52 \mathrm{~mm}, 8,38 \pm 0,60 \mathrm{~mm}, 13,20 \pm 0,99 \mathrm{~mm}$ e 39,46 $\pm 1,46 \mathrm{~mm}$, respectivamente. Para análise molecular, foram obtidas e analisadas as sequências do gene COI. A média das divergências intraespecíficas de Nyctalus leisleri foi de $0,04 \%$. As divergências interespecíficas médias de Nyctalus noctula e Nyctalus leisleri foram de $0,2 \%$. A concentração média de cada nucleotídeos foi $\mathrm{A}=26,3 \%, \mathrm{~T}=32,8 \%, \mathrm{G}=15,9 \%$ e $\mathrm{C}=25 \%$. Os conteúdos médios de $\mathrm{A}+\mathrm{T}$ foram de $59,2 \%$ e de C + G foram de 40,9\%. Na árvore filogenética, Nyctalus leisleri e Nyctalus noctula agruparam-se com um valor significativo de suporte de bootstrap.

Palavras-chave: Nyctalus leisleri, morfologia, Agência Kurram, Agência Khyber, Paquistão.

\section{Introduction}

The genus Nyctalus (Bowdich, 1825) includes seven species N. noctula, N. leisleri, N. lasiopterus, N. planci, N. azoreum,

$N$. montanus and N. velutinus. In the Indian Subcontinent it is represented by a single genus and three species

*e-mail: muzafar@uswat.edu.pk

Received: May 20, 2020 - Accepted: July 28, 2020 
including Nyctalus noctula (Schreber, 1774), Nyctalus leisleri (Kuhl, 1819) and Nyctalus montanus (Barrett-Hamilton, 1906) (Roberts, 1997; Bates and Harrison, 1997). In Pakistan only two species have been reported till now. The first one was reported from Gharial in Murree Hills at $2385 \mathrm{~m}$ while the second from Kululai, Yakh Tangai at Swat Kohistan with height of $1850 \mathrm{~m}$ in 1972 by Dr Walton, (Walton, 1974). The same species ranges from low elevation plains (Ruczynski and Ruczynska, 2000) up to mountain forests in Europe (Hruz et al., 2000; Spitzenberger and Bauer, 2001).

It is migratory species in Europe and occurred in northern Himalayan region of Pakistan (Walker et al., 1964). It is not mentioned in Siddiqi's (1961, 1970) checklists. It is believed that these species migrate to Pakistan in summer, although specimens were collected from the Murree Hills as late as $8^{\text {th }}$ November. The District Swat Kohistan species were collected on $1^{\text {st }}$ September, hunting in open area however Walton did not find its roost.

It was also collected from Palgham in Indian Kashmir from Kumaon and Simla further east, so it have fairly widely distributed in the better forested regions of Himalayans. In Pakistan, it appears to have associated with possible mesic conditions in the Himalayan, moist temperate forest zone. It is very numerous and probaily does not appear to be highly gregarious.

Only two species have been reported from two provinces of Afghanistan i.e. Paktia province (Meyer-Oehme, 1965) and Jalalabad (Gaisler, 1970). It is very rare in Afghanistan while not reported from Iran yet. On $18^{\text {th }}$ March a male was reported near Jalalabad which are very active sexually (Gaisler, 1970).

This medium sized insectivorous bat specializes with aerial for fast hawking and their body (forearm length 40-47 mm, body mass $9-20 \mathrm{~g}$ was reviewed by Bogdanowicz and Ruprecht, 2004). This species emerges in early to hunt, like many of the Pipistrellus species and often active before sunset. They have strong and superb flight and feed from small to medium-sized insects (Nematocera, Trichoptera, Coleoptera, and Lepidoptera (Nowak, 1991; Beck, 1995; Vaughan, 1997; Shiel et al., 1998, Waters et al., 1999; Fuhrmann et al., 2002). Exclusively they built roosts in tree-hollows (Ruczyñski and Bogdanowicz, 2005), except Ireland, where nursery colonies occupy roof attics (Shiel et al., 1999). The purpose of present study is to broaden the scope to understanding about the morphology and distribution of N. leisleri in Pakistan.

\section{Materials and Methods}

\subsection{Study area}

The study was conducted in selected areas (Kurram agency and Khyber Agency) of FATA region. It is among agencies in Federally Administered Tribal Area (FATA). The Kurram gency head quarter is Parachinar, while that of Khyber is Jamrud. The agency is bordered in the north and west by Afghanistan (province of Paktiya and Ningarhar respectively), Orakzai and Khyber agencies in the East, Kohat to the South and North Waziristan to the West (Figure 1). The Kurram Agency is divided into mainly three administrative units Upper Kurram, Lower Kurram and Central Kurram while Khyber Agency is divided into Bara, Jamrud, Landi kotel and Torkham. Kurram Agencies is surrounded by series of mountains on about all sides. Most importing striking physical feature is the Koh-E-Sufid covered by snow for almost whole the year. Main mountain range in the study area is the Koh-E-Sufid with peak of Sikaram about 4,628 m high meeting a boundary with Afghanistan. It remains about cover with snow throughout the year (Hussain, 2007).

\subsection{Method}

The study was conducted from May 2013 to August 2015 in all possible and accessible areas of FATA regions. This was a pioneering attempt to identify the poorly known bat fauna of this area. Bats samples were collected from (a) Upper (b) Central (c) Lower Kurram Agency and adjacent areas in order to identify bat fauna of these areas up to species level through morphological features, which were used throughout the world (Dobson, 1876; DeBlase, 1980; Bates and Harrison, 1997; Roberts, 1997; Dietz and Von-Helversen, 2004).

\subsection{Sampling strategy}

Exploratory visits were made for locating as many bat roosts in all the sub-areas as possible. Potential bat roosts such as old and ruined buildings, abandoned wells, farmhouses, tree groves and forest plantations were searched properly. Local people were interviewed for gaining possible information about the exact territory of various bat roosts.

For collection of bats a fine quality, black, UV strong mist nets were used. On a pair of $3 \mathrm{~m}$ long bamboo poles the mist nest were erected either in "L" or "V" shape about one foot above the ground. The nets were ready to operate about half an hour before the sunset and opened simultaneously before sunset and continued to operate, depending on the weather conditions, for two hours. Nets were checked regularly to disentangle any captured of bat. The sampling effort throughout the study remained the same.

Once located the bats roost, global position of each of roost was determined using Garmin etrax H Global Position System (GPS).

\subsection{External morphology}

The capture bats were collected in cloth bags containing wet cotton and were brought directly to the laboratory. The bats were then weighted, their sex and age was calculated (Wołk and Ruprecht, 1988).

Each bat weighed up to $0.1 \mathrm{~g}$ (Pesola balance 10050, Swiss made), Field number, age, Sex, exact location and agency were noted. The external body measurements were taken using a digital Varner caliper $(0-150 \mathrm{~mm})$. Age of each captured bat specimen was determined following Dietz (2005).

\subsection{Cranial measurements}

The tongue, eye balls and excessive flesh was removed from the skull for recording cranial measurement. Skulls were cleaned and kept in a dilute solution ( $0.2 \%$ of Potassium Hydroxide $(\mathrm{KOH})$ overnight and absolute alcohol for other night before being transferred to acetone for the third night (Figure 2). 


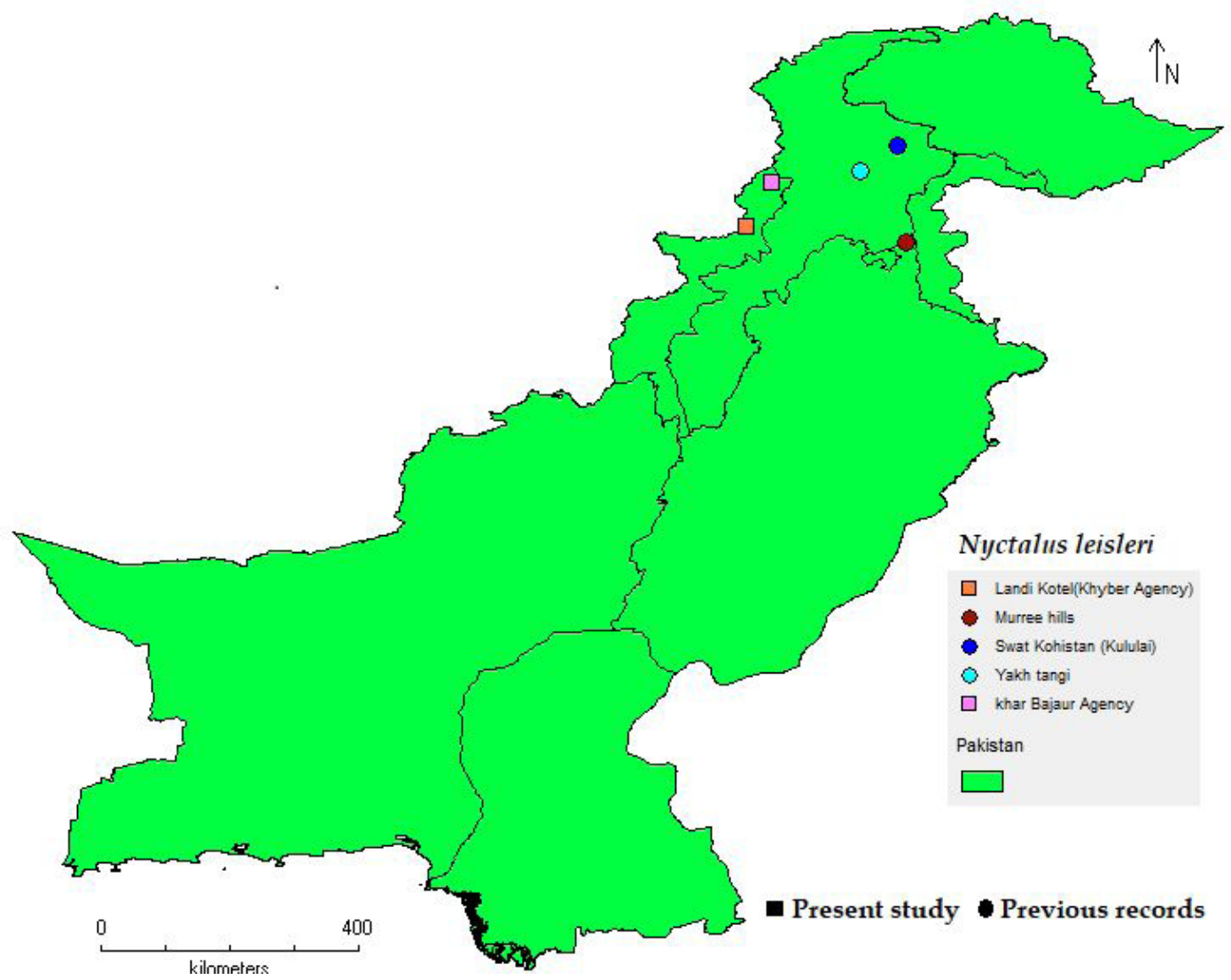

Figure 1. Localities and distribution of Nyctalus leisleri in Pakistan.

\subsection{Molecular identification and Phylogenetic analysis}

\subsubsection{Extraction of DNA}

The Thermo scientific Gene JET Genomic DNA purification Kit was used for the extraction of DNA from wing membrane of the ethanol-preserved specimens. For the amplification of $\mathrm{COI}$ gene, the following primers (Table 1) were used (Folmer et al., 1994).

\subsubsection{Amplification of COI gene}

PCR reaction was performed in a final volume i.e $25 \mu \mathrm{L}$ containing $10 \mu \mathrm{L}$ of Thermo scientific Dream Taq Green PCR Master Mix, $1 \mu \mathrm{L}$ forward primer, $1 \mu \mathrm{L}$ reverse primer, $0.5 \mu \mathrm{L}$ Taq polymerase, $1 \mu \mathrm{L}$ template DNA and $6.5 \mu \mathrm{L}$ nuclease free water. The amplification conditions were 1 cycle, $95^{\circ}$ for 5 minutes, 35 cycles, $94^{\circ} \mathrm{C}$ for 30 seconds, $48{ }^{\circ} \mathrm{C}$ for 30 seconds, $72{ }^{\circ} \mathrm{C}$ for $35 \mathrm{~s}, 1$ cycle, $72{ }^{\circ} \mathrm{C}$ for 10 minutes, hold at $4{ }^{\circ} \mathrm{C}$.

\subsubsection{DNA sequence analysis}

The sequences were used for the identification of species through NCBI BLAST search. Divergence at species, generic and family level were employed the K2P model of base substitution. Sequences of congeneric specimens deposited by other workers were also taken from Gene Bank using Blast tool for the comparisons and analysis of genetic distance. The sequences were also aligned in clustalW. NeighbourJoining tree was constructed using K2P parameter and 1000 bootstrap replicates. The Maximum likelihood was constructed using best substitution model with 1000 bootstrap replicates. Maximum Parsimony approach was employed by using Tree-Bisection-Reconnection (TBR) parameter and 1000 bootstrap replicates. All analysis was performed by using MEGA 7 software.

\section{Results and Discussion}

After extensive field surveys five Leisler's Bat Nyctalus leisleri (Kuhl, 1817) were collected from study area and compared their external body and cranial features with Roberts (1997) and Bates and Harrison (1997), the best authentic sources on bats of the region. This bat is medium-sized insectivorous with forearm length ranging in 43.10 to 44.60 . The pelage is longer and denser than other. The dorsal surface mainly darker while the ventral surface is buffy brown. The wings are sharp and long extend to the ankle of hind foot. The ear is blackish and naked, both anterior and hind margins being convex when viewed from another side. There is a low, broad tragus its anterior margin being sharply concave and posterior margin almost in straight position. Our findings are in line with Bates and Harrison (1997) and Roberts (1997). 

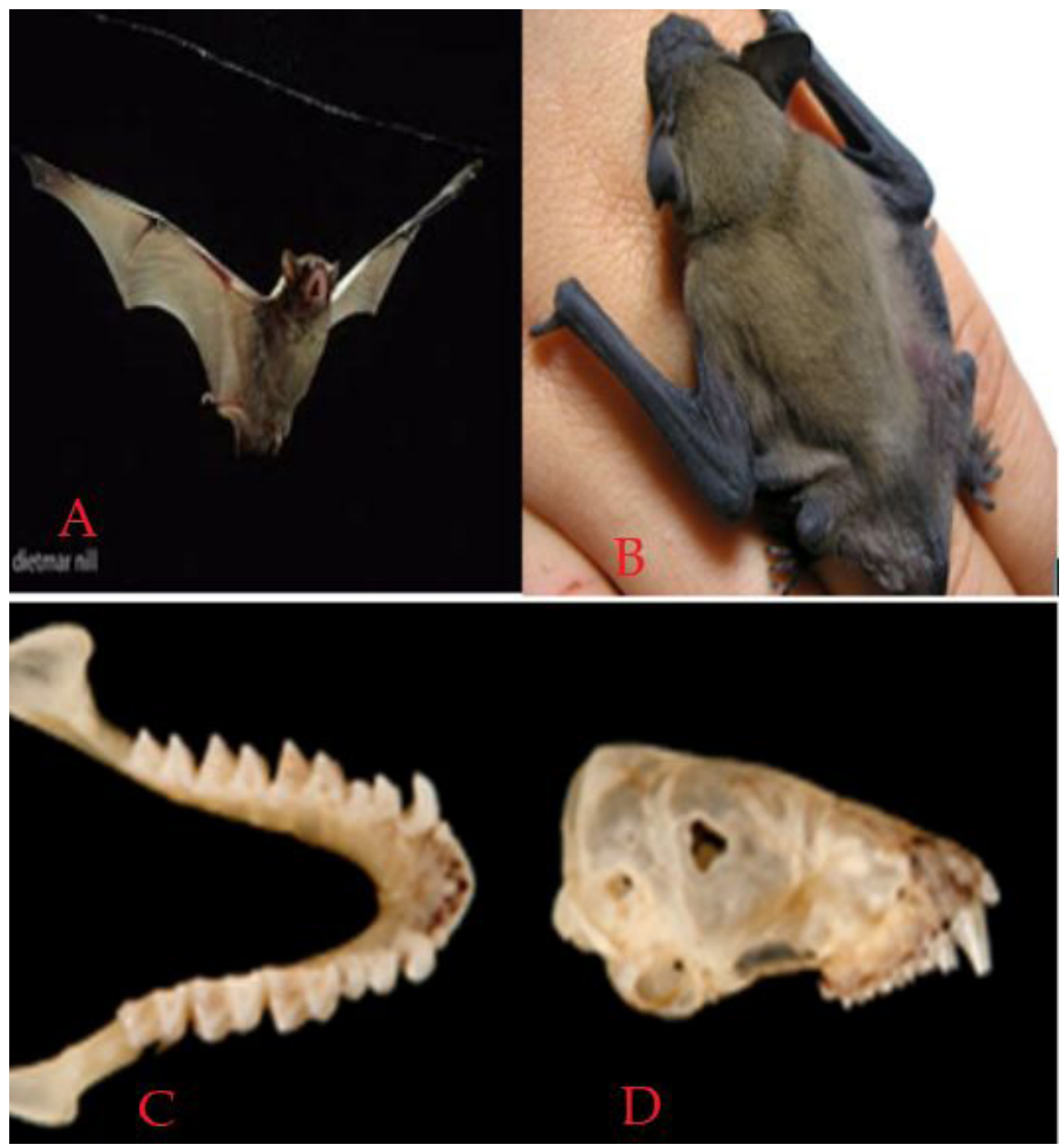

Figure 2. (A) Nyctalus leisleri; (B) Head; (C) Skull lateral view; (D) Lower jaw dorsal view.

Table 1. Primer pair for COI gene amplification.

\begin{tabular}{ccc}
\hline Primer code & & Primer sequence \\
\hline COX-F2 & Forward & 5'-GGTCAACAAATCATAAAGATATTGG-3' \\
COX-R1 & Reverse & 5'-TAAACTTCAGGGTGACCAAAAAATCA-3' \\
\hline
\end{tabular}

Average head and body length of 05 specimens collected during present study was $65.08 \pm 1.58 \mathrm{~mm}$, forearm length was $44.06 \pm 0.52 \mathrm{~mm}$, hind foot length was $8.38 \pm 0.60 \mathrm{~mm}$, ear length was $13.20 \pm 0.99 \mathrm{~mm}$ and the tail was $39.46 \pm 1.46 \mathrm{~mm}$ long while according to Roberts (1997), the average head and body length, forearm length, hind foot length, ear length and tail length was $67 \mathrm{~mm}, 39-46 \mathrm{~mm}, 8 \mathrm{~mm}, 10.7 \mathrm{~mm}$ and
$36 \mathrm{~m}$, respectively. All these measurements fall within the ranges given by Roberts (1997) and Bates and Harrison (1997). The mean body mass of five Leisler's Bat was $14.326 \pm 1.93 \mathrm{~g}$ while according to Chirichella et al. (2003), Kaňuch et al. (2005) and Mathias (1988), the mean body mass were $14.50 \pm 0.71 \mathrm{~mm}, 15.05 \pm 0.55 \mathrm{~mm}, 15.32 \pm 1.73 \mathrm{~mm}$ and 11-20 mm, respectively (Table 2 ). 


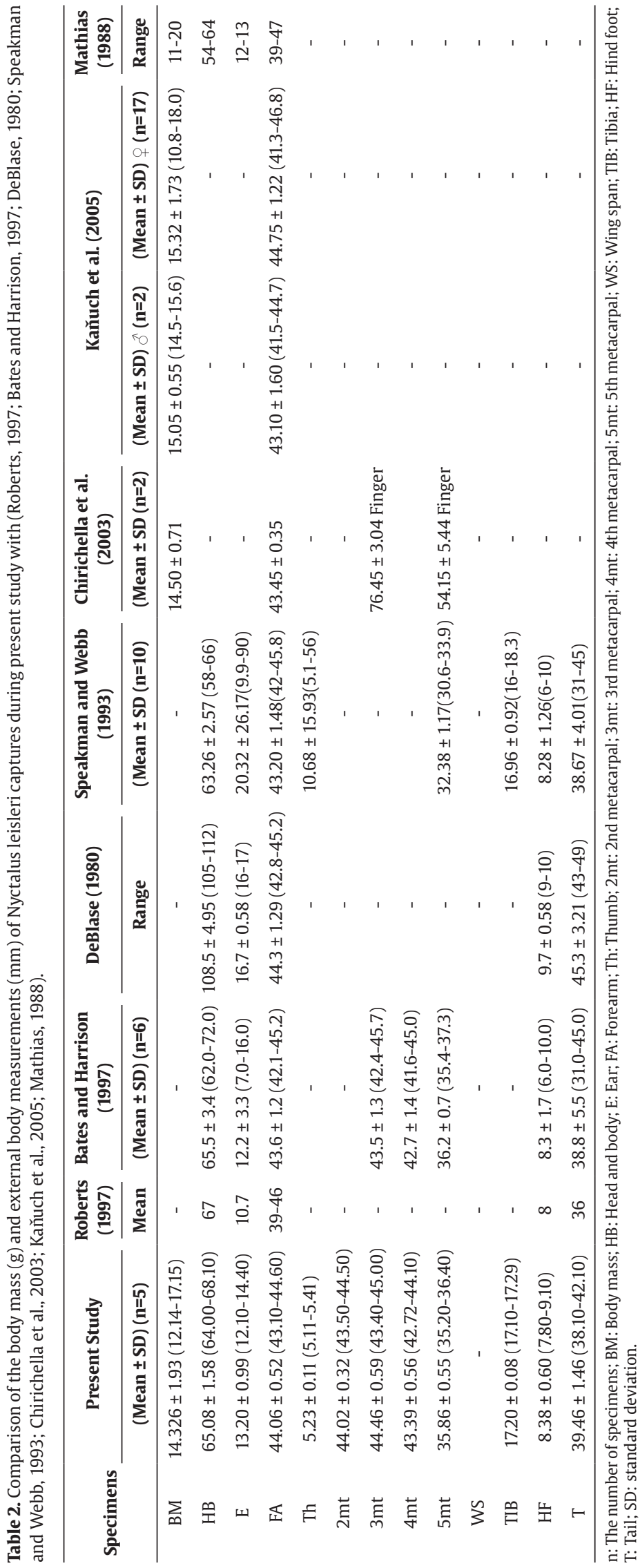


Average greatest length of skull $(\mathrm{n}=5)$ of Nyctalus leisleri specimens was $15.50 \pm 0.07 \mathrm{~mm}$, breadth of brain case was found $8.42 \pm 0.07 \mathrm{~mm}$ and zygomatic bone was observed $10.38 \pm 0.08 \mathrm{~mm}$ long. The inter-orbital constriction was $4.78 \pm 0.07 \mathrm{~mm}$, condylocanine length was found $14.60 \pm 0.33 \mathrm{~mm}$ while posterior palatal widths was $7.28 \pm 0.07 \mathrm{~mm}$. The maxillary toothrow length, mandibular toothrow length and mandible length was $5.60 \pm 0.17 \mathrm{~mm}, 6.18 \pm 0.07 \mathrm{~mm}$ and $11.60 \pm 0.06 \mathrm{~mm}$ respectively (Table 3 ).

The sequence of COI gene of species belonging to genus, obtained in the present study was compared to other gene sequences using NCBI, BLAST. The similarity indexes with other sequences of the same species were from $99-100 \%$. Theses sequences were also studied for deviations of nucleotide and their composition. Sequences of DNA of seven species belong to single genus was procured to Gene Bank deposited by other coworkers.
The final aligned data had seven sequences of more than 556 bp length represent seven species. All the barcode gaps were distinct among species. In sequence no overlap deviation was observed. The collected data aligned was shown by 556 characters of which were conserved sites was 486 , variable sites 70 , parsimony informative sites 68 , and singleton sites 2 . The increase in the mean $\mathrm{K} 2 \mathrm{P}$ deviations was observed. The mean intraspecific deviation of Nyctalus noctula was $0.02 \%$. The mean intraspecific divergences of Nyctalus leisleri was $0.04 \%$. The mean interspecific divergences of Nyctalus noctula and Nyctalus leisleri was $0.2 \%$ (Table 4 ).

The compositions of nucleotide sequences of all species were also observed. Nucleotide mean concentration was $\mathrm{A}=(26.3 \%), \mathrm{T}=(32.8 \%), \mathrm{G}=(15.9 \%)$ and $\mathrm{C}=(25.0 \%)$. The mean $\mathrm{A}+\mathrm{T}$ contents were $59.2 \%$ and $\mathrm{C}+\mathrm{G}$ were $40.9 \%$ (Table 5 ).

Table 3. Comparison of the cranial measurements (mm) of Nyctalus leisleri (Roberts, 1997; Bates and Harrison, 1997; DeBlase, 1980; Mathias, 1988).

\begin{tabular}{ccccc}
\hline Specimens & $\begin{array}{c}\text { Present Study }(\mathbf{n}=\mathbf{5}) \\
(\mathbf{m e a n} \pm \mathbf{~ S D})\end{array}$ & $\begin{array}{c}\text { Bates and Harrison } \\
(\mathbf{1 9 9 7})(\mathbf{m e a n} \pm \mathbf{S D})(\mathbf{n}=\mathbf{6})\end{array}$ & DeBlase (1980) & Mathias (1988) \\
\hline $\mathrm{CBL}$ & - & - & $15.3 \pm 0.42(15-15.6)$ & $14.50-15.20$ \\
$\mathrm{CM}^{\mathrm{n}}$ & $5.60 \pm 0.17(5.40-5.80)$ & $5.7 \pm 0.1(5.5-5.9)$ & $5.5 \pm 0.28(5.3-5.7)$ & - \\
$\mathrm{CM}_{\mathrm{n}}$ & $6.18 \pm 0.07(6.10-6.30)$ & $6.1 \pm 0.2(5.9-6.3)$ & $6.2 \pm 0.00(6.2-6.2)$ & - \\
$\mathrm{GTL}$ & $15.50 \pm 0.07(15.40-15.60)$ & $15.6 \pm 0.2(15.3-15.9)$ & $16.0 \pm 0.07(15.9-16)$ & $11.10-11.20$ \\
$\mathrm{M}$ & $11.60 \pm 0.06(11.50-11.70)$ & $11.6 \pm 0.2(11.4-11.7)$ & $11.7 \pm 0.00(11.7-11.7)$ & - \\
$\mathrm{M}^{\mathrm{n}}-\mathrm{M}^{\mathrm{n}}$ & $7.28 \pm 0.07(7.20-7.40)$ & $7.1 \pm 0.2(6.9-7.4)$ & - & - \\
$\mathrm{ZB}$ & $10.38 \pm 0.08(10.30-10.50)$ & $10.3 \pm 0.4(9.8-10.7)$ & $10.3 \pm 0.00(10.3-10.3)$ & - \\
$\mathrm{BB}$ & $8.42 \pm 0.07(8.30-8.50)$ & $8.3 \pm 0.1(8.2-8.5)$ & - & - \\
$\mathrm{IO}$ & $4.78 \pm 0.07(4.70-4.90)$ & $4.7 \pm 0.1(4.6-4.9)$ & $4.6 \pm 0.14(4.5-4.7)$ & - \\
$\mathrm{RW}$ & $6.42 \pm 0.19(6.10-6.70)$ & $6.6 \pm 0.1(6.4-6.8)$ & & - \\
\hline
\end{tabular}

CBL: Condylo-basal length; $\mathrm{CM}^{\mathrm{n}}$ : Maxillary toothrow; $\mathrm{CM}_{\mathrm{n}}$ : Mandibular toothrow; GTL: Greatest length of skull; M: Mandible length; $\mathrm{M}^{\mathrm{n}}-\mathrm{M}^{\mathrm{n}}$ : Posterior palatal width; ZB: Zygomatic breadth; BB: Breadth of braincase; IO: Interorbital Width; RW: Rostral width.

Table 4. Pairwise genetic distance of genus Nyctalus (Bowdich, 1825).

\begin{tabular}{lllllll}
\hline JF443048 Nyctalus noctula & & & & & & \\
FR856759 N. noctula & 0.002 & & & & & \\
MK091913 N. leisleri & 0.143 & 0.146 & & & & \\
JF443043 N. leisleri & 0.143 & 0.146 & 0.007 & & & \\
JF443042 N. leisleri & 0.148 & 0.151 & 0.007 & 0.004 & 0.000 & 0.000 \\
GU270566 N. leisleri & 0.148 & 0.151 & 0.007 & 0.004 & 0.000 & 0.002 \\
FR856758 N. leisleri & 0.148 & 0.151 & 0.007 & 0.004 & 0.002 & 0.002 \\
FR856755 N. leisleri & 0.146 & 0.148 & 0.005 & 0.002 & & \\
\hline
\end{tabular}

Table 5. Composition of base percentage wise in gene COI of genus Nyctalus leisleri.

\begin{tabular}{ccccc}
\hline Base & A & T & G & C \\
\hline Mean percentage\% & 26.3 & 32.8 & 15.9 & 25.0 \\
\hline
\end{tabular}


The Neighbor Joining tree was constructed into two clades i.e. clade I and clade II. Clade I comprised upon six sequences, the sequences of Nyctalus leisleri of the present study was among them (Figure 3).

The Maximum Likelihood tree having log likelihood $(-2812.83)$ with same topography to Neighbor Joining tree. Conspecific taxa clumped with 61-100\% supported bootstrap (Figure 4).
The Maximum Parsimony tree having length (469), index consistency (0.5419199) index retention $(0.714078)$ and index composite $(0.414135)$ was contracted with same topography to Neighbor Joining tree and Maximum Likelihood tree (Figure 5).

These observations confirm the utility of the COI gene sequence of Nyctalus leisleri, obtained in the current analysis for identification to species level.

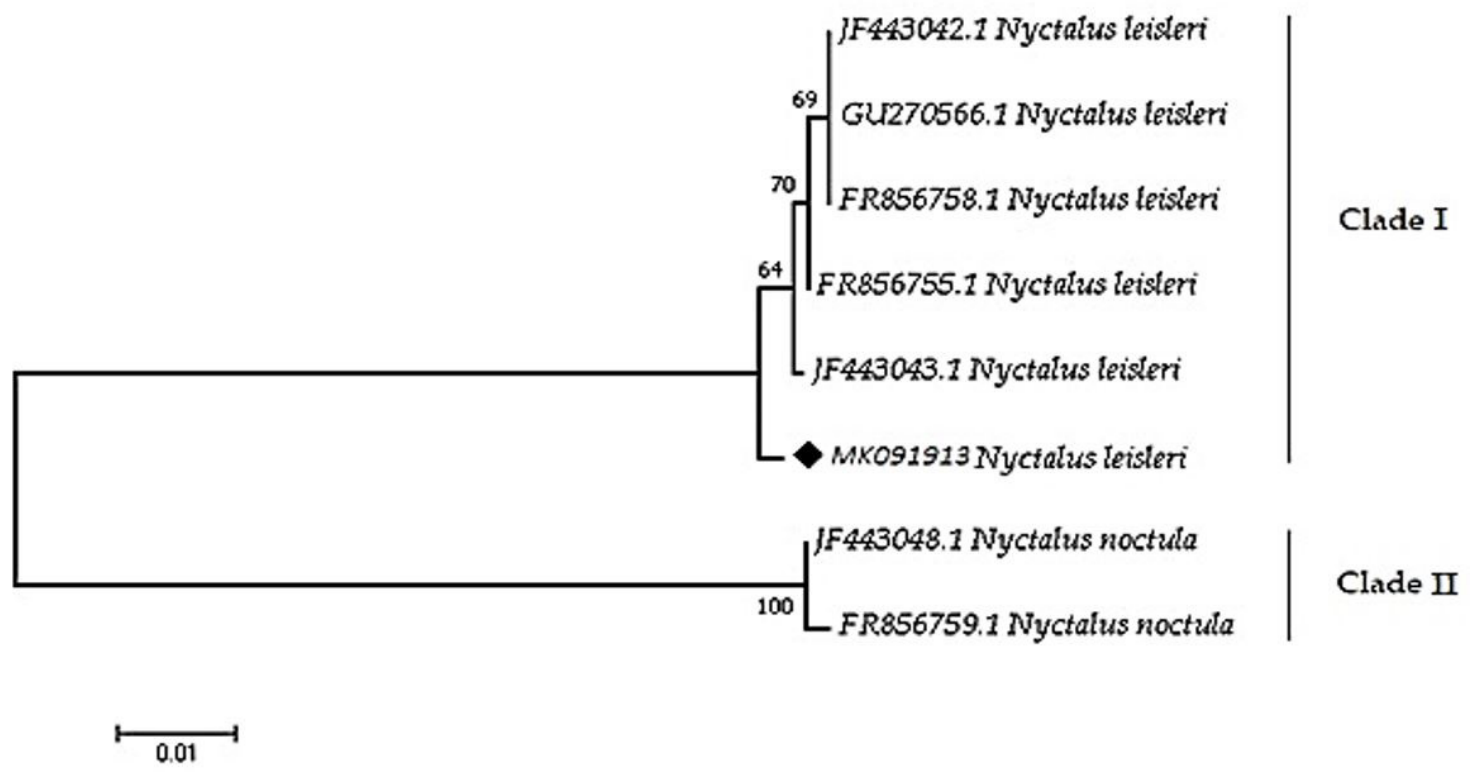

Figure 3. Genus Nyctalus peculiar to COI by Neighbour Joining method. Number shows percent of 1000 bootstraps replication above 50. - shows the sequences of species of the present research.

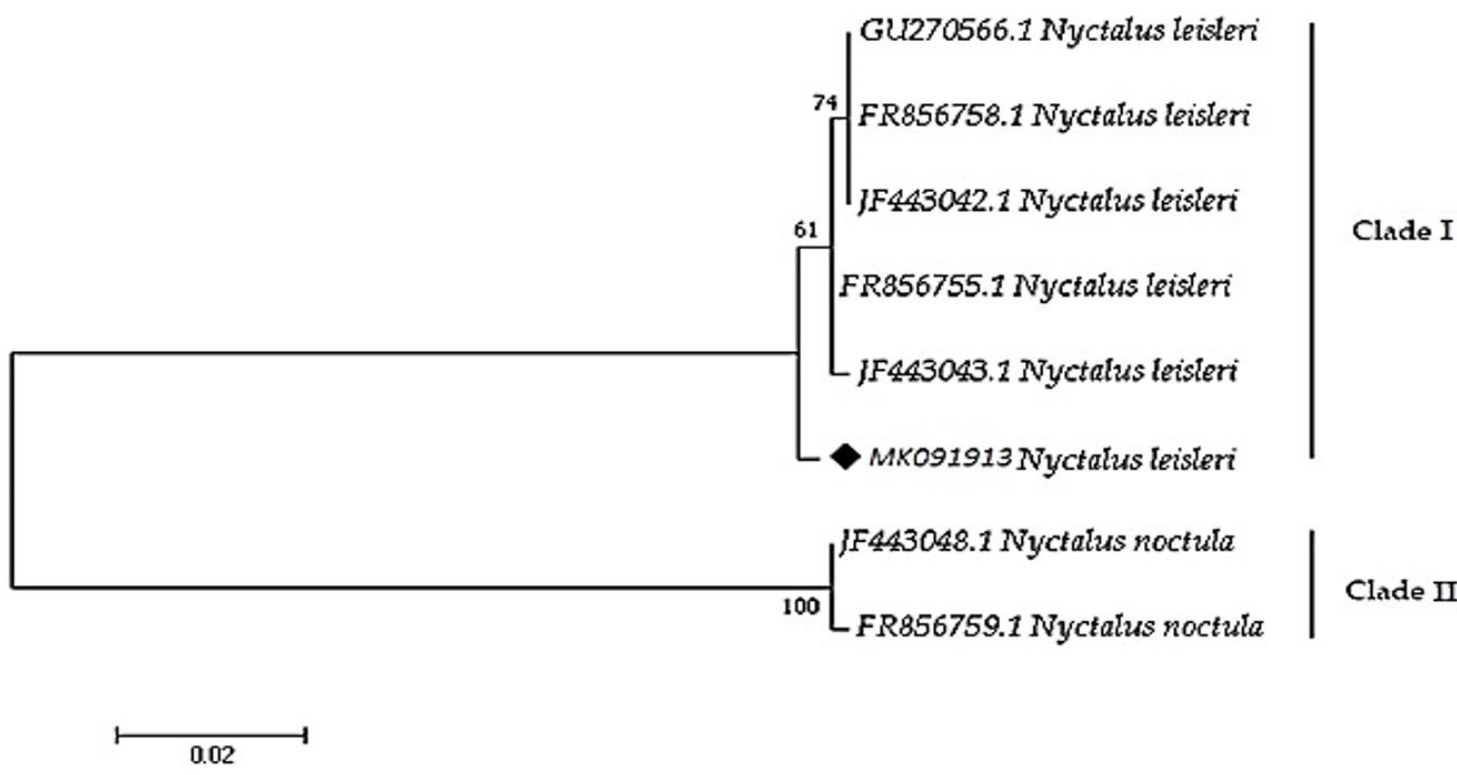

Figure 4. Genus Nyctalus peculiar to COI by Maximum likelihood method. Number shows percent of 1000 bootstraps replication above 50 . shows the sequences of species of the present research. 


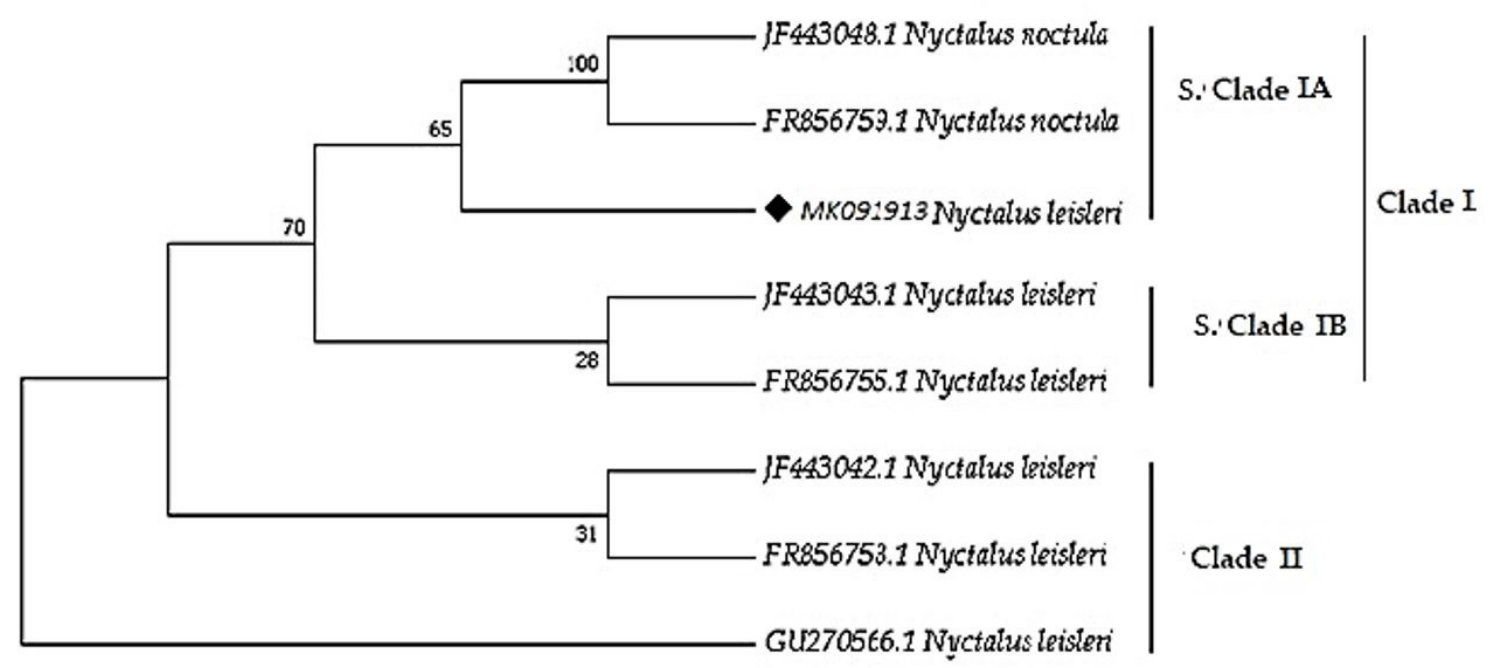

Figure 5. Peculiar to COI by Maximum parsimony method (K2P model). Numbers show percent of 1000 bootstraps replication above 50. - shows the sequences of species of the present research.

\section{References}

BARRETT-HAMILTON, G.E.H., 1906. Description of two new species of Pterygistes. Annals \&' Magazine of Natural History, vol. 17, no. 97, pp. 98-100. http://dx.doi.org/10.1080/00222930608562496.

BATES, P.J.J. and HARRISON, D.L., 1997. Bats of the Indian subcontinent. Sevenoaks, UK: Harrison Zoological Museum, pp. 254-258.

BECK, A., 1995. Fecal analyses of European bat species. Myotis, vol. 32, no. 33, pp. 109-119.

BOGDANOWICZ, W. and RUPRECHT, A.L., 2004. Nyctalus leisleri Kleinabendsegler. In: F. KRAPP, ed. Handbuch der Säugetiere Europas. Band 4/II: Fledertiere (Chiroptera) II. Wiebelsheim: Aula-Verlag, vol. 10, pp. 582-585.

BOWDICH, T., 1825. Excursions in Madeira and Porto Santo. Journal of Zoology, vol. 249, pp. 173-180.

CHIRICHELLA, R., MATTIROLI, S., NODARI, M., PREATONI, D.G., WAUTERS, L.A., TOSI, G. and MARTINOLI, A., 2003. The AdamelloBrenta Natural Park bat community (Mammalia, Chiroptera): distribution and population status. Hystrix the Italian Journal of Mammalogy, vol. 14, pp. 29-45.

DEBLASE, A.F., 1980. The bats of Iran: systematics, distribution, ecology. Fieldiana. Zoology, vol. 4, no. 1, pp. 421-424.

DIETZ, C. and VON-HELVERSEN, O., 2004. Illustrated identification key to the bats of Europe. Germany: Dietz \& von Helversen, vol. 1, pp. 1-74

DIETZ, C., 2005 [viewed 20 May 2020]. Illustrated identification key to the bats of Egypt. Version 1.0 [online]. Germany. Available from: http://www.le-vespere.org/ docs/telechargements/ Dietz_2005_BatsEgypt.pdf

DOBSON, G.E., 1876. Monograph of the Asiatic Chiroptera, and catalogue of the species of bats in the collection of the Indian museum, Calcutta. London.

FOLMER, O., BLACK, M., HOEH, W., LUTZ, R. and VRIJENHOEK, R., 1994. DNA primers for amplification of mitochondrial cytochrome coxidase subunit I from diverse metazoan invertebrates. Molecular Marine Biology and Biotechnology, vol. 3, no. 5, pp. 294-299. PMid:7881515.

FUHRMANN, M.,SCHREIBER, C.H. and TAUCHERT,J.,2002. Telemetrische Untersuchungen an Bechsteinfledermäusen (Myotis bechsteinii) und Kleinen Abendseglern (Nyctalus leisleri) im Oberurseler Stadtwald und Umgebung (Hochtaunuskreis). In: A. MESCHEDE, K.-G.
HELLER, and P. BOYE, eds. Ökologie, Wanderungen und Genetik von Fledermäusen in Wäldern Untersuchungen als Grundlage für den Fledermausschutz. Bonn-Bad Godesberg: Bundesamt für Naturschutz, vol. 288. no. 1, pp. 131-140. Schriftenreihe für Landschaftspflege und Naturschutz, no. 71.

GAISLER, J., 1970. The bats (Chiroptera) collected in Afghanistan by the Czechoslovak expeditions of 1965-1967. Acta Scientiarum Naturalium Academiae Scientiarium Bohemoslovacae Brno, vol. 4, pp. 1-56.

HRÚZ, V., KRIŠTÍN, A. and URBAN, P., 2000. Bats of the Po3/4ana Mts. (Central Slovakia). Vespertilio, vol. 4, pp. 97-104.

HUSSAIN, W., 2007. File to medicinal study of FATA. Khyber Pakhtunkhw: Department of Zoology, Kohat University of Science and Technology, pp. 13-17. M. Phil Thesis in Zoology.

KAŇUCH, P., KRIŠTÍN, A. and KRIŠTOFÍK, J., 2005. Phenology, diet, and ectoparasites of Leisler's bat (Nyctalus leisleri) in the Western Carpathians (Slovakia). Acta Chiropterologica, vol. 7, no. 2, pp. 249-257. http://dx.doi.org/10.3161/1733-5329(2005)7[249:PD AEOL]2.0.CO;2.

KUHL, H., 1819. Die deutschen Fledermause. Annalen der Wetterauischen Gesellschaf, vol. 4, pp. 11-49, 185-215.

MATHIAS, M.L., 1988. An annotated list of the mammals recorded from the Madeira Islands. Boletim do Museu Municipal do Funchal, vol. 40, no. 201, pp. 111-137.

MEYER-OEHME, D., 1965. Die-Säugetiere Afghanistans (Teil III): Chiroptera. Kabul, Afghanistan: Science, pp. 42-58.

NOWAK, R., 1991. Order Chiroptera in Walker's Mammals of the World. Baltimore: Johns Hopkins University Press, vol. 5, no. 1, pp. $190-194$.

ROBERTS, T.J. (1997). Mammals of Pakistan. Oxford: Oxford Univ. Press.

RUCZYŇSKI, I. and BOGDANOWICZ, W., 2005. Roost cavity selection by Nyctalus noctula and N. leisleri (Vespertilionidae, Chiroptera) in Białowieża primeval forest, Eastern Poland. Journal of Mammalogy, vol. 86, no. 5, pp. 921-930. http:// dx.doi.org/10.1644/1545-1542(2005)86[921:RCSBNN]2.0.CO;2.

RUCZYŇSKI, I. and RUCZYŇSKA, I., 2000. Roosting sites of Leisler's bat Nyctalus leisleri in Białowieża Forest preliminary results. Myotis, vol. 37, pp. 55-60. 
SHIEL, C., DUVERGÉ, P., SMIDDY, P. and FAIRLEY, J., 1998. Analysis of the diet of Leisler's bat (Nyctalus leisleri) in Ireland with some comparative analyses from England and Germany. Journal of Zoology, vol. 246, no. 4, pp. 417-425. http://dx.doi. org/10.1111/j.1469-7998.1998.tb00173.x.

SHIEL, C.B., SHIEL, R.E. and FAIRLEY, J.S., 1999b. Seasonal changes in the foraging behaviour (Nyctalus leisleri) in Ireland as revealed by radio-telemetry. Journal of Zoology, vol. 249, no. 3, pp. 347-358. http://dx.doi.org/10.1111/j.1469-7998.1999. tb00770.x.

SIDDIQI, M.S., 1961. Checklist of mammals of Pakistan with particular reference to the mammalian collection in the British Museum (Natural History), London. Biologia, vol. 7, pp. 93-225.

SIDDIQI, M.S.U., 1970. On some bats of the Oriental Region. Records Zoological Survey of Pakistan, vol. 2, pp. 1-9.

SPEAKMAN, J.R. and WEBB, P.I., 1993. Taxonomy, status and distribution of the Azorean bat (Nyctalus azoreum). Journal of Zoology, vol. 231, no. 1, pp. 27-38. http://dx.doi. org/10.1111/j.1469-7998.1993.tb05350.x.
SPITZENBERGER, F. and BAUER, K., 2001. Weißrandfledermaus Pipistrellus kuhlii (Kuhl, 1817). In: F. SPITZENBERGER, ed. Die Säugetierfauna Osterreichs. Graz: Bundesministerium für Landund Fortswirtschaft Umwelt und Wasserwirtschaft, pp. 245-248.

VAUGHAN, N., 1997. The diets of British bats (Chiroptera). Mammal Review, vol. 27, no. 2, pp. 77-94. http://dx.doi. org/10.1111/j.1365-2907.1997.tb00373.x.

WALKER, E.P., WARNICK, F., LANGE, K.I., UIBLE, H.E., HAMLET, S.E., DAVIS, M.A. and WRIGHT, P.E., 1964. Mammals of the world. Baltimore: Johns Hopkins Press, I: ixlviii, 1644, figs, 5 tables.

WALTON, D.W., 1974. New records of bats (Chiroptera) from Pakistan. Journal of the Mammalogical Society of Japan, vol. 6, no. 2, pp. 43-50.

WATERS, D., JONES, G. and FURLONG, M., 1999. Foraging ecology of Leisler's bat (Nyctalus leisleri) at two sites in southern Britain. Journal of Zoology, vol. 249, no. 2, pp. 173-180. http://dx.doi. org/10.1111/j.1469-7998.1999.tb00755.x.

WOŁK, E. and RUPRECHT, A.L., 1988. Haematological values in the serotine bat, Eptesicus serotinus (Schreber, 1774). Acta Theriologica, vol. 33, no. 40, pp. 545-553. http://dx.doi. org/10.4098/AT.arch.88-45. 